\title{
The Philosophical Meanings of Tapis Limar Sekebar and Bintang Perak: A Semiotic Perspective of Charles Sanders Peirce
}

\author{
Hanifa Sa'diyah"'I Wayan Suardana, Rapi Renda
}

\author{
Faculty of Language and Arts, Yogyakarta State University, Yogyakarta, Indonesia \\ *Corresponding author. Email: hanifasadiyah11@gmail.com \\ Email: wayan_suardana@uny.ac.id \\ Email: dkampoeng.20@gmail.com
}

\begin{abstract}
This study aimed to examine the philosophical meanings of the Tapis Limar Sekebar and Bintang Perak. This research was conducted at Kediangan Gallery, Lampung. The research employed a descriptive qualitative method with the Charles Sanders Peirce's semiotic approach. The data collection techniques included documentation, interviews, and observations. The data were then analyzed through data reduction, data display, and conclusion drawing. The results indicate that the Tapis Limar Sekebar and Bintang Perak have philosophical meanings that represent the community life in Lampung. (1) the Tapis Limar Sekebar provides rhombus, sasab, and flower motifs. It has a meaning that can be regarded as a basis for human behavior to maintain good attitudes and deeds; people must help each other, remember that the owned sustenance is only a gift from God used to do kindness, be knowledgeable based on the customary and religious norms, and a job/duty properly and systematically. (2) Tapis Bintang Perak contains motifs of stars, tajuk berayun, and gunung lampu (mountains of lights). It has a meaning as a basis for the wearers' behavior to become human beings who always maintain a relationship with God, others, and with the natural surroundings.
\end{abstract}

Keywords: Tapis, Tapis Limar Sekebar and Tapis Bintang Perak, Philosophical Meanings, Semiotics

\section{INTRODUCTION}

Indonesia is recognized with the motto 'Unity in Diversity', because it has a variety of ethnic groups, cultures, and customs with different characteristics in each region. Culture is a view of life that develops in a certain community which is preserved and passed from generation to generation. Culture is all human activities such as science, beliefs, arts, laws, morals, customs, and other habits that humans acquire as members of society [1]. One of the Indonesian cultures is the tradition of textile fabrics. Meanwhile, tradition is an effort made by humans to meet the needs of life, relying on their capabilities by considering nature as an object that can be managed to meet people's necessities. Therefore, the birth of the culture is triggered by the human desire to fulfill their daily needs, in the forms of behavior, lifestyle, economy, agriculture, kinship system, social stratification, religion, myth, and so on. The textile tradition has played many roles in various activities such as in the social, spiritual, and practical fields over the centuries. Each ethnic group and society in Indonesia has different characteristics in its traditional textile fabrics as the ancestors' cultural heritage, particularly in the Lampung community.

Lampung is one of the provinces in Indonesia, located on the Sumatra island, which has a tradition of textile fabrics. Lampung's textile tradition is known as tapis. Tapis fabric is one of the handicrafts made by the Lampung people with the weaving technique. The tapis making has an aim to harmonize life with the Creator of the Universe and the environment. Tapis Lampung is regarded as a traditional craft because the basic tools used to make it and its decorative motifs are simple and processed manually. Lampung has a motto "Sai Bumi Khua Jukhai" which means One Earth Two Branches. Meanwhile, "Sai Bumi (one earth)" is interpreted as an ethnic group inhabiting one area and coming from the same descent, and "Khua Jukhai (Two Branches)" is defined as two types of custom in the community, namely Pepadun (inland) people and Saibatin (coastal) people.

In the 16th century during the Sultanate of Banten, the Pepadun custom was established. The community living 
with the Pepadun custom consists of Abung Siwo Mego, Mego Pak Tulang Bawang, Pubian Telu Suku, Buay Lima Way Kanan, and Sungkai Bunga Mayang. The Mego Pak Tulang Bawang ethnic group are spread across four customary areas, namely Menggala, Mesuji, Panaragan, and Wiralaga. The Tulangbawang tribe is under the customary law of Pepadun. The meaning of Mego Pak is that the Tulang Bawang ethnic group has four mego (clans), namely Buay Umpu, Buay Bulan, Buay Aji, Buay Tegamoan [2].

In this study, the researchers studied the tapis from Mego Pak Tulang Bawang. It has many types of tapis motif, such as dewasano, limar sekebar, ratu tulang bawang, bintang perak, limar tunggal, sasab, kilap turki, jung sarat, kaco mato di lem, kibang, cukkil, and cucuk sutero. However, the authors limited the research problem by only investigating the philosophical meanings of Tapis Limar Sekebar and Tapis Bintang Perak through the semiotic perspective of Charles Sanders Peirce.

\section{LITERATURE REVIEW}

\subsection{Tapis}

Initially, tapis was a sarong made using fine cotton threads, which had sugi motifs embroidered with silver or gold threads [3].

\subsection{Semiotics}

Semiotics or semiology comes from the Greek word "semeion" which is defined as a sign. It is the study of sign systems such as languages, codes, signals, and so on. Semiotics is a theory of general philosophy with regard to the production of signs and symbols as part of a code system used to communicate information. Semiotics includes visual and verbal signs, and tactile and olfactory senses (all signs that can be accessed and felt by all our senses) when these signs form a system of codes that systematically convey information or messages in writing in every activity and human behavior [4]. Umberto Eco in his book entitled A Theory of Semiotics says that semiotics has a relationship with various things that can be interpreted as signs. A sign is everything interpreted as a significant substitute for something else [5]

Semiotics by Peirce is defined as the study of signs and everything related to them; how to function (syntactic semiotic), the relationship among signs (semantic semantics), and examines the sender and receiver by those who use the signs (semiotic pragmatics). Therefore, according to Peirce, signs are not only related to language and culture, but also to all natural phenomena (pansemiotics). For Peirce, the nature of signs has a fundamental principle, namely the representative and interpretive natures. The representative nature of a sign means that it is understood as something that represents something else, while the interpretive nature means that the sign provides opportunities for interpretation depending on the user and recipient. In this context, Peirce sees that the process of significance is important because humans contribute meaning to the reality they encounter. According to Peirce, this implies that language is closely related to reality, and for him, signs start from human cognition dynamically.

Peirce views that in semiotics, there is a triadic relationship between the representamen $(\mathrm{R})$, object $(\mathrm{O})$, and interpretant (I). Thus, semiosis is the process of interpreting signs starting from perceptions (ground; representamen), and then ground (ground; representamen) leads to the object; finally, the interpretant process occurs. Thus, for Peirce, semiotics is an action, influence, or cooperation of three subjects: sign, object, and interpretant [6]. Also, according to Pierce, signs always bring meaning to human life. Furthermore, the meaning has message content as communication to the audience/appreciator of visual objects. Signs are not a structure but part of the understanding process (communication significance).

Peirce states that language is closely related to reality because semiosis is a gradual configuration of methods to interpret reality. In interpreting reality, the subject understands the effect of signs. The sign effect has trichotomic classifications elaborated as follows:

a. Firstness is the level of understanding the subject and the existence of signs that are still potential, full of probability, and feeling. It is regarded as the potential implementation stage.

b. Secondness is the level of understanding the subject and the existence of signs dealing with reality when the subject comprehends the presence of reality. This stage is known as the implementation of actuality.

c. Thirdness is the level of understanding the subject and the existence of signs when they are formulated with the general accepted rules to constitute the subject's understanding of reality. The final stage is called abstraction [6].

Peirce employed three logical paths to see everything in studying objects as follows.

1. Relationship between Representamen (R) and Type of Representamen:

a. qualisign: there is a relationship between the representamen and the quality or color;

b. sinsign: there is a relationship between the representamen and the real facts;

c. legisign, there is a relationship between the representamen and the first (law) rule.

2. The relationship between the Object (O) and Representamen Type (R; Ground): 
He also classifies three types of signs based on the reference side (typology of signs), namely, icons, indexes, and symbols.

a. Icon. The relationship between the representation $(\mathrm{R})$ and the object $(\mathrm{O})$ has a similarity (similitude or resemblance) or "unequal imitation" with the form of the object (seen in a picture or painting).

b. Index. There is a relationship between the representamen (B) and the object (O) because there is a causal relation between the ground and the object.

c. Symbol or actual sign; the occurrence of the relationship between the representamen $(\mathrm{R})$ and the object $(\mathrm{O})$ is due to the convention.

3. The relationship between the Interpretant (I) and the Type of Representamen (R):

a. Rheme or seme, i.e., representamen which still has various probabilities to be interpreted by the interpreter;

b. Dicent or dicisign, i.e., representamen which has a certain meaning and can be considered as real facts;

c. Argument, i.e., representamen that has been connected to certain rules or prepositions [6].

\section{RESEARCH METHOD}

This was qualitative research which was processed into descriptive data. According to Bogdan and Biglen, qualitative data analysis is an activity that deals with data, organizes data into manageable units, synthesizes, identifies patterns, finds what is important and what is learned, and decides what can be shared with others [7]. This research was conducted at Kediangan Gallery, Jl. Narada, Jaga Baya I, Way Halim, Bandar Lampung City, Lampung. Tapis Lampung was used as the object of research because it is one of the traditional cultures $\backslash$ and plays a role in the customary activities of the Lampung people. Therefore, it needs to be preserved, one of which is by making scientific writing which will later become a relevant source to find out the philosophical meaning in the Tapis Lampung.

In this study, the data collection techniques used were observation, interviews, and visual documentation. The data obtained were then analyzed through data reduction and data presentation. The data reduction was carried out by summarizing the data, selecting the main information, focusing on the significant things, and then removing the unnecessary [8]. After the data were reduced, they were displayed and clarified. After that, the researchers drew conclusions or did verification to write the report.

This research employed the Charles Sander Pierce's semiotic study to investigate the signs and philosophical meanings in the Pepadun traditional tapis of Lampung, namely Tapis Limar Sekebar and Bintang Perak, to preserve one of the Indonesian wealth. Also, the researchers found out its uses, users, and what events the Tapis Lampung is worn. Due to the globalization era with the advancement in many aspects such as technology and fashion, this condition is regarded as hyperreality. Hyperreality is a condition that transcends the understanding of reality, a world that reproduces, grows, moves, and mutates as if it has no purpose, no foundation, no control, no code, and no meaning [9]. The era development that surely cannot be avoided must be faced and balanced with efforts to preserve the cultural values.

There are several stages in this research: first, collecting the primary and secondary data sources related to the objects under study, i.e., Tapis Limar Sekebar and Tapis Bintang Perak; Second, conducting a semiotic analysis of the Tapis Limar Sekebar and Tapis Bintang Perak by connecting to various data sources to understand the cultural context of the signs and symbols in the two tapis of the area of Mego Pak Tulang Bawang; Third, Charles Sanders Pierce's semiotic approach will be used to examine the visual signs (a language of visual signs) in the two tapis through the Charles Sanders Pierce's semiotic approach to find the philosophical meaning.

To read the visual objects of Tapis Limar Sekebar and Tapis Bintang Perak, the Charles Sander Pierce's triadic semiotic approach (three basic elements) was employed by the researchers. The approach includes the representation [sign $=\mathrm{T}$; thing], object [O; something in human cognition], and interpretation [I; interpretation process]. According to Pierce, human life cannot be separated from signs, and signs always contain meaning. Furthermore, the meaning contains messages as a means of communication to the audience/appreciators of visual objects (Tapis Limar Sekebar and Tapis Bintang Perak).

\section{DISCUSSION}

\subsection{Tapis Limar Sekebar and Tapis Bintang Perak}

The tapis making has its own meaning for the Lampung people as a life harmony to the environment and the Creator of the Universe. The community tries to always live side by side with nature by putting various kinds of natural wealth in tapis embroidery. Therefore, the natural motif is used as decoration by the traditional tapis craftsmen. Images of flora and fauna are the main choice of the Tapis Lampung craftsmen. Therefore, we will find the motifs of birds, elephants, bamboo shoots, and so on on the traditional tapis. The area where the tapis artists live is the source of their imagination and creations. Their places to live affect the results of their creations. A motif is a design made from parts of a shape, various lines, or elements, which are sometimes strongly influenced by the stylized forms of nature, objects, with their own distinctive styles and characteristics [10]. 
The tapis craftsmen find ideas from everyday life that take place around the environment where they live. For example, people who live in the inland areas (Lampung Pepadun) select the land life as decoration, for example, flowers and land animals [11]. Likewise, Tapis Limar Sekebar and Tapis Bintang Perak were created by employing the surrounding life inspiration in its manufacture. Each tapis motif has different functions and meanings, so if people want to wear a tapis, they must understand the procedures for using it. Tapis Limar Sekebar and Bintang Perak include geometric motifs depicted in the decoration. Tapis Limar Sekebar, based on its customs is intended for groups of wives attending traditional events and for mulei (Lampung girls) as the bridesmaids in wedding ceremonies. Meanwhile, the Tapis Bintang Perak in customs is worn by the bride during the traditional wedding party and by elderly women as wives of people with a Sutan title.

The first tapis was a type of clothing worn on the chest down; in the Java area it is known as "jarik". Therefore, tapis was a term for Lampung tribal women's clothing, not a type of handicraft with embroidery techniques [11]. Tapis at that time was produced manually. The equipment used to make the basic fabrics and decorative motifs was simple. Tapis was woven by women, both housewives and mulei-mulei (Lampung girls) to spend their spare time to meet the demands of cultural activities that are considered sacred. Also, tapis was only worn by women to attend traditional events.

Tapis Lampung is now known as one of the traditional crafts with embroidery techniques. This is because nowadays it is not used by women as a garment from the chest down but from the waist down. Along with its development, today's tapis is not only in the form of a sarong, but also in the form of dresses, scarves, Muslim caps, and even wall decorations and calligraphy. Also, tapis is worn by not only women but also men as tumpal (the outer layer of trousers). The motifs are also increasingly varied; the producers develop previous motifs by following the current trends. Based on an interview conducted on August 9, 2020, with the owner of the Kediangan Gallery, Mr. Raswan explained:

"The cultural dynamics will continue to develop; some will go extinct; some will appear, and some will survive. The culture that survives is named preservation. Apart from preservation, there is also development. Before modern times, everything was traditional. But now it is different, some have been left behind, but some are still being maintained".

In addition to the increasingly varied motifs, the basic tapis making tools have also developed in modern times because they are being produced at factories, and the tapis is no longer woven manually and traditionally. Furthermore, Raswan on 9 August 2020 explained:

"Even though the current tapis still applies the old pattern, it is not completely the same because the materials used are different from those in the past. Also, apart from the complicated manufacture, the price of the material is very expensive, causing the tapis craftsmen to make tapis at a more affordable price and of course, the quality is not as good as that in the past".

The condition, which is beyond the development of the latest technology and science, has created a world with boundaries. It is regarded as hyperreality by some thinkers, particularly, Jean Baudrillard and Umberto Eco [9]. In the world of hyperreality, certainty and originality become something blurry and fragile. For example, it happens to the current tapis, where the use of it ignores its designation. This illustrates that the era of modernization, where technology continues to develop, provides not only positive impacts but also negative impacts that need to be coped with. One of them is the development of tapis-making tools that can make the production easier, and the more variety of the motifs, the more varied and interesting they will be, particularly in the world of fashion which is increasingly in demand. However, if this is not balanced with basic knowledge about tapis culture and its ethics of use, it is feared that it can erode the culture of the tapis itself.

\subsection{The philosophical meanings of Tapis Limar Sekebar and Bintang Perak through the Charles Sanders Peirce's Semiotic Perspective}

\subsubsection{Tapis Limar Sekebar}

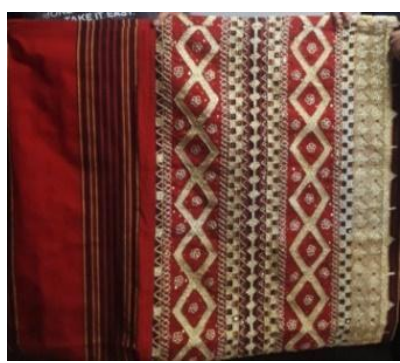

Figure 1. Tapis Limar Sekebar

The interpretation at the initial level of Charles Sander Pierce's semiotic triadic on the Tapis Limar Sekebar as shown in Figure 1 is a sign (defined as something that represents something else) that will be analyzed. The object on the Tapis Limar Sekebar is a rhombus motif, a pattern derived from geometric motifs, and a pattern that has a parallelogram shape, the four sides of which have the same length, and each line of which meets and forms an angle. The pattern is then embroidered using gold threads on the fabric with a red base color; the large rhombus pattern is not embroidered with gold thread; the middle part remains the same to have a space showing the basic color of the fabric, which is given a different motif, i.e., the small-size flower pattern to create a more attractive impression with the right proportions; thus, harmony is created in the object. For the interpretation, the balanced side explains that it is important to always maintain good behavior and actions for the common interest, such as helping others, because 
sustenance is only a gift from God that should be used for society, not only for one's needs.

The second object is the sasab motif. The motif has a small-size rhombus pattern that is fully embroidered with gold threads, arranged in a line horizontally on the edge of the fabric so that the basic color is not visible. The object filled with gold thread embroidery is interpreted as having a lot of significant knowledge, both physically and mentally based on the prevailing customary and religious norms.

The third object is a flower motif that has a small-size pattern with five semi-circular curved petals. It is embroidered with gold threads. The object is lovely, beautiful, attractive, fragrant, and it is a scenic product of plants so that it can be interpreted that every action and work must be completed carefully, beautifully, and interestingly to obtain a satisfactory process and result.

Tapis Limar Sekebar is worn by groups of wives to attend traditional events and by mulei (Lampung girls) as bridesmaids in wedding ceremonies. If the visual form of the Tapis Limar Sekebar is connected to its use, there will be a philosophical meaning in it. This meaning can be understood as a basis for the wearers' behavior in order to maintain good deeds and actions, help each other, remember that the sustenance owned is only a gift from God which must be used to help others through sharing with the poor. In addition, be a woman who has a lot of useful knowledge appropriate for the customary and religious norms. People should do their work efficiently and precisely to obtain a satisfactory result based on the expectations.

\subsubsection{Tapis Bintang Perak}

The interpretation at an early stage of the Charles Sander Pierce's semiotic triadic for the Tapis Bintang Perak can be found in Figure 2 below. Tapis Bintang Perak is the analyzed sign (interpreted as a thing that represents something else). The object on the Tapis Bintang Perak is a large-size star motif that is fully embroidered with gold threads and a red base color.

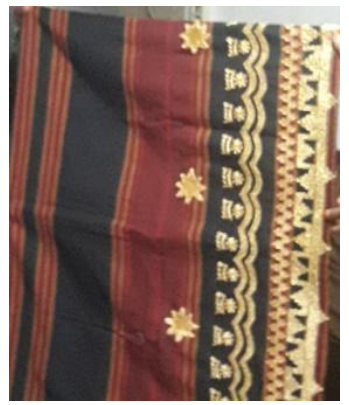

Figure 2. Tapis Bintang Perak

Then, the star motif is placed with a distance between one object and another. Also, there are smaller star motifs on the tapis with a black base color. The star is embroidered with gold threads as if it has a light that can illuminate its surroundings. Therefore, it is interpreted as always trying to be a source of light for many people. If you want to be respected and honored by others, you must respect and honor others as well.

The second object in the Tapis Bintang Perak is the tajuk berayun motif, which is a geometric shape depicted in a decorative form with the triangular motif. The motif is embroidered with gold threads on a black base and on the edge of the fabric. It is illustrated in a triangle connected by a line with other isosceles triangles, depicting energy that is stable or has a balance and showing a steady strength. It is interpreted as being resolute in the position that has been agreed so that it is not affected by negative things, but it remains flexible in following the current development of the era.

The third object in the Tapis Bintang Perak is the gunung lampu (mountain of light) motif, a type of geometric motif depicted in a decorative form. The shape is triangular, and it is embroidered with gold threads and a red base color. The motif is depicted in a decorative triangle form, which belongs to a geometric type. The triangle of the gunung lampu can be interpreted as a relationship concept with God, human, and nature. In short, it can be interpreted that it is important to maintain a relationship with God, human, and the natural environment; people should not try to find other people's mistakes, behave properly according to the customs, preserve the traditions, take advantage of every kindness, and respect others.

Tapis Limar Sekebar is worn by the bride during the traditional wedding ceremony and by elderly women as the wives of people who have acquired the title of Sutan. Regarding its use, the visual form of Tapis Bintang Perak has a philosophical meaning in it. This meaning can be understood as the basis for the wearers' behavior to become human beings who always maintain a relationship with God by worshiping and with others by helping each other, honoring, and respecting others to gain respect and honor too. Also, people need to maintain a relationship with the surrounding environment by behaving properly in accordance with the customs and preserving the traditions; to be a resolute person; and to perform stable energy even though they have to keep up with the globalization era.

\section{CONCLUSIONS}

Recent developments in technology and science have created a world that transcends its boundaries; this phenomenon is known as hyperreality by some thinkers, especially Jean Baudrillard and Umberto Eco [9]. In the world of hyperreality, certainty and originality are blurry and fragile. What happened to the current tapis is one of the examples, where the use of it no more pays attention to its purposes. This illustrates that the era of modernization, where technology continues to develop, can provide both positive and negative impacts to be dealt with. Also, it happens to the development of tapis production tools that can support the manufacture, and the more variety of the motifs, the more varied and 
interesting they will be, particularly in the world of fashion that is increasingly in demand. However, if this is not balanced with basic knowledge about tapis culture and its ethics of use, it is feared that it can erode the culture of the tapis itself. This research identified the philosophical meanings in the Tapis Limar Sekebar dan Tapis Bintang Perak.

Based on the research findings and discussion on the motifs of the Tapis Limar Sekebar dan Tapis Bintang Perak, the philosophical meanings in each of the tapis motifs are identified: (1) Tapis Limar Sekebar has rhombus, sasab, and flower. It has the meanings of maintaining good behavior and deeds, helping each other, realizing that the owned sustenance is only a gift from God, which must be used to help others, acquiring a lot of useful knowledge appropriate for the customary and religious norms, and doing a job effectively and carefully; (2) Tapis Bintang Perak has motifs such as stars, tajuk berayun, and mountains of lights. Those have meanings as a basis for the wearers' behavior to become human beings who always maintain a relationship with God, others, and the natural surroundings.

\section{REFERENCES}

[1] Ratna, N. K. Metodologi penelitian kajian budaya dan ilmu sosial humaniora pada umumnya [Research methodology in cultural studies and social sciences, humanities in general]. Pustaka Pelajar, 2019.

[2] Syah, I. Bunga rampai adat budaya Lampung [Potpourri of Lampung cultural customs]. Histokultura, 2017.
[3] Hartono, L. Kain tapis Lampung perubahan fungsi, motif dan makna simbolisnya [Lampung's filter cloth changes its function, motif and symbolic meaning]. Doctoral dissertation, Universitas Gadjah Mada, 2004.

[4] Susanto, M. Diksi Rupa: Kumpulan Istilah dan Gerakan Seni Rupa [Visual diction: a collection of terms and fine arts movements]. DictiArt Lab, 2011.

[5] Berger, A. A. Pengantar Semiotika: Tanda-tanda dalam Kebudayaan Kontemporer [Introduction to Semiotics: Signs in Contemporary Culture]. Tiara Wacana, 2010.

[6] Rusmana, Dadan. Filsafat Semiotika [Semiotic Philosophy]. CV Pustaka Setia, 2014.

[7] Moleong, L. J. Metodologi Penelitian Kualitatif [Qualitative Research Methodology]. PT Remaja Rosdakarya Offset, 2009.

[8] Sugiyono. Metode Penelitian Pendidikan [Educational Research Methods]. Alfabeta, 2018.

[9] Piliang, Yasraf Amir. Teori Budaya Kontemporer: Penjelajahan Tanda \& Makna [Contemporary Cultural Theory: The Exploration of Signs \& Meanings]. Cantrik Pustaka, 2018.

[10] Suhersono, H. Desain bordir motif fauna [Fauna motif embroidery design]. Gramedia Pustaka Utama, 2005.

[11] Eko, S. B. Mengenal Ragam Sulaman Tapis Lampung [The Variety of Lampung Tapis embroidery]. Pelita Lestari, 2012. 